\title{
PERANAN MODAL KULTURAL DAN STRUKTURAL DALAM MENCIPTAKAN KERUKUNAN ANTARUMAT BERAGAMA DI BALI
}

\author{
Halimatusa'diah \\ Lembaga Ilmu Pengetahuan Indonesia (LIPI) Jakarta \\ Halimatusadiah8015@gmail.com \\ Artikel diterima 5 Maret, diseleksi 23 Mei, dan disetujui 25 Juni 2018
}

\begin{abstract}
Several accidents related to Ahmadiyah in Cikeusik, Shi'ism in Sampang, or in Tanjung Balai, are among intolerance disasters which often colour the realities of Indonesian diverse society. However, within some other diverse societies like Bali, we also find societies which are able to maintain religious harmony and peaceful life. This study aims at describing any factors that has supported religious harmony in Bali. This is important in order to overcome any religion-related conflict in Indonesia, as well as to establish religious harmony. Employing qualitative approach, this study discovers that the establishment of tolerance and religious harmony in Bali has mostly been influenced by the factor of historical exemplary. The strong cultural and structural capitals of Bali have also strongly supported this harmony. The cultural capital taking the form of local wisdom that have always been maintained, harmony agents such as conserver of tradition, as well as FKUB (Forum Kerukunan Umat Beragama/Forum for Religious Harmony) have significant roles in conserving and establishing religious harmony in Bali.
\end{abstract}

Keywords: Bali, Tolerance, Religious Harmony, Intolerance, Local Wisdom.

\section{PENDAHULUAN}

Kerusuhan yang terjadi di Tanjung Balai, Sumatera Utara merupakan ekspresi intoleransi dan kekerasan yang tidak semestinya terjadi (Hasani, 2016) ${ }^{1}$.

1http://www.tribunnews.com/regional/2016/ 07/31/peristiwa-tanjung-balai-bukti-meningkatnyaintoleransi

\begin{abstract}
Abstrak
Peristiwa Ahmadiyah di Cikeusik, Syiah di Sampang, hingga kasus Tanjung Balai, merupakan berbagai peristiwa intoleransi yang kerap mewarnai realitas masyarakat kita yang majemuk. Namun, di beberapa wilayah lain dengan masyarakatnya yang juga beragam, seperti di Bali, kita juga bisa menemukan masyarakat yang mampu menjaga kerukunan antarumat beragamanya dan hidup secara berdampingan. Penelitian ini bertujuan untuk mendeskripsikan berbagai faktor yang menjadi penyangga kerukunan antarumat beragama di Bali. Kajian ini penting dilakukan untuk mengatasi berbagai konflik agama yang terjadi di Indonesia, serta bagaimana menciptakan kerukunan antarumat beragama. Dengan menggunakan pendekatan kualitatif, penelitian ini menemukan bahwa terciptanya toleransi dan kerukunan antarumat beragama di Bali, selain dipengaruhi oleh faktor keteladanan sejarah, juga dikarenakan Bali memiliki modal kultural dan modal struktural yang kuat. Modal kultural berupa kearifan lokal yang masih terus terjaga dan juga agen-agen kerukunan seperti penjaga tradisi dan FKUB juga berperan besar dalam menjaga dan menciptakan kerukunan antarumat beragama di Bali.
\end{abstract}

Kata kunci: Bali, Toleransi, Kerukunan Antarumat Beragama, Intolerasi, Kearifan Lokal.

Peristiwa ini menjadi cerminan bahwa intoleransi masih mewarnai kehidupan masyarakat kita. Di berbagai daerah, intoleransi memang kerap mewarnai realitas kehidupan sosial masyarakat Indonesia yang majemuk. Penyerangan terhadap jemaat HKBP Filadelfia di Bekasi Jawa Barat, penyegelan, perusakan, 
pembakaran masjid Ahmadiyah di Tasikmalaya dan Bekasi, Pengusiran Syi'ah di Sampang Jawa Timur, Ahmadiyah di Cikeusik (Wahid Institute, 2012; INFID, 2013), merupakan fenomena keberagamaan di Indonesia yang selalu terjadi.

Toleransi yang dimaknai sebagai kerukunan dalam perbedaan, ${ }^{2}$ mensyaratkan adanya penerimaan dan penghargaan terhadap pandangan, keyakinan, nilai, serta praktik orang/ kelompok lain yang berbeda dengan kita (Khisbiyah, 2007:4). Indonesia memang tidak memiliki UU tersendiri tentang toleransi antarumat beragama. Namun, rumusan pasal-pasal yang mengatur kebebasan beragama dalam berbagai peraturan perundangan sesungguhnya telah menunjukkan isi toleransi antarumat beragama. Sebagai contoh, Pasal 29 ayat (2) UUD 1945 menyatakan bahwa negara menjamin tiap-tiap penduduk untuk memeluk agamanya masing-masing dan untuk beribadat menurut agama dan kepercayaannya. Memang tidak ada kata-kata toleransi di situ, namun tersirat di dalamnya tentang pesan jika negara menjamin kebebasan beragama, maka seluruh masyarakat dari berbagai agama juga harus ikut menjamin demikian. Dengan begitu maka setiap penganut agama, termasuk dari agama yang berbeda, harus saling menghormati kebebasan orang lain untuk memeluk agamanya dan beribadat menurut agamanya itu.

Kebijakan-kebijakan keagamaan yang ada, yang berlaku secara nasional justru dinilai kerap menimbulkan konflik. Mengutip sejumlah laporan, seperti disitir INFID (2013); Hefner \& Ali Fauzi (2014); Wahid Institute (2014); HRW (2013);

2 United Nations Educational, Scientificand Cultural Organization (UNESCO) Toleransi adalah rasa hormat, penerimaan dan apresiasi terhadap keragamanbudaya dunia kita, berbagai bentuk ekspresi diri dan cara-cara menjadi manusia. Hal ini didorong oleh pengetahuan, keterbukaan, komunikasi, dan kebebasan berpikir, hati nurani dan keyakinan. Toleransi adalah kerukunan dalam perbedaan.

\begin{tabular}{l|l} 
HARMONI & Januari - Juni 2018
\end{tabular} dan Suprapto (2012), justru menemukan adanya peraturan perundang-undangan yang dibuat sebagai turunan dari UUD 1945, bertentangan dengan semangat kebebasan beragama. Hal ini berimplikasi pada pengabaian atas hak warga negara, dalam hal ini minoritas agama untuk bebas beragama atau berkeyakinan.

International NGO Forum on Indonesia Development (INFID) dalam laporan penelitiannya antara lain menyebutkan, bahwa aturan hukum tentang pendirian tempat ibadah, penistaan agama dan pelarangan aktivitas Ahmadiyah justru telah mendorong para pelaku pelanggaran. Ekspresi-ekspresi publik tentang agama dalam bentuk kekerasan dan intoleransi beragama kerap tak terhindarkan (INFID, 2013).

Di sisi lain, kapasitas masyarakat dan negara dalam mengelola keragaman seringkali diperlemah oleh kurangnya sinergi antarelemen dalam masyarakat. Respons terhadap isu keragaman seringkali didasarkan pada opini, kecurigaan, atau kesalahpahaman daripada pengetahuan yang akurat berbasis riset. Akibatnya, tidak jarang potensi kekerasan bukan hanya tidak bisa dicegah, tetapi bahkan upaya menangani konflik keagamaan justru melanggengkan masalah. Makin berkurangnya penghargaan atas asas Bhinneka Tunggal Ika yang dianggap menyimbolkan kemajemukan dan toleransi (Muhtadi 2011; Salim HS 2011), masalah-masalah dalam demokrasi di Indonesia seperti Pilkada yang juga memberi ruang bagi para politisi untuk "menjual" agama (ICG 2008; Bush 2008; Hamid 2012). Dengan demikian, menciptakan kerukunan umat beragama menjadi tantangan tersendiri bagi masyarakat kita yang majemuk. Selain persoalan-persoalan di atas, fakta yang tidak bisa diabaikan adalah tingkat kemampuan masyarakat dalam mengelola kemajemukan, beragam dari satu tempat ketempat lain. 
Studi-studi tentang kerukunan umat beragama biasanya lebih banyak dikaitkan dengan situasi konflik, diskriminasi, maupun kekerasan terhadap minoritas agama ${ }^{3}$. Sementara, perhatian terhadap keberhasilan berbagai wilayah dalam meredam konflik dan mengelola keragaman di tengah pluralitas masyarakat Indonesia masih kurang memadai. Padahal di beberapa tempat, seperti NTT dan Bali, ${ }^{4}$ ditemukan komunitas-komunitas dengan penduduk yang berbeda identitas agama, mampu hidup secara berdampingan dalam kurun waktu yang lama. Namun sayangnya tidak cukup ada upaya untuk menjelaskan, mempublikasikan dan mentransfer kemampuan satu masyarakat dalam mengelola keragaman ke tempat lain sehingga potensi kekerasan di wilayahwilayah yang rentan bisa diatasi.

Riset ini ingin mengisi kekurangan dan keterbatasan yang disisakan oleh studi-studi di atas, khususnya keberhasilan suatu daerah dalam mengelola keragaman dan membangun relasi sosial yang harmonis antar

3 Di antara beragam kasus terkait isu toleransi dan kebebasan keagamaan keyakinan di Indonesia, dua jenis yang paling menonjol, sebagaimana ditunjukkan dalam berbagai laporan yang terbit dalam beberapa tahun terakhir ini, adalah terkait dengan tuduhan penodaan agama dan pendirian rumah ibadah (INFID 2013; HRW 2013). Penerbitan serangkaian kebijakan dan peraturan menjadi legitimasi kelompok mayoritas untuk meminggirkan kelompok minoritas. Sejumlah Studi yang juga dilakukan oleh lembaga-lembaga pemantau kebebasan beragama menunjukkan makin meningkatnya kekerasan terhadap minoritas agama seperti Ahmadiyah dan, belakangan, kelompok Syiah (Cholil et.al., 2013; Naipospos et.al., 2013; dan Azhari dan Nisa 2012). Sejumlah laporan lainnya menunjukkan kegagalan aparat negara dalam menangani sengketa dan konflik terkait tempat ibadat dan kekerasan sektarian. Polisi sebagai aparat negara seringkali tidak dapat bertindak tegas terhadap pihak-pihak yang jelas-jelas melanggar hak kelompok tertentu untuk bebas beragama atau berkeyakinan atau tunduk kepada tekanan kelompokkelompok dominan dalam masyarakat (Asfinawati et.al., 2008; Kontras 2012; ICG 2008 dan 2012).

4 Survey Kerukunan Umat Beragama tahun 2015, menggunakan skala 0-100 memeroleh rerata nasional 75,36, yang berarti berada pada kategori kerukunan tinggi. Kerukunan tinggi yang dimaksud dalam penelitian ini adalah bekerjanya dimensi kerukunan, yaitu: toleransi $(71,26 \%)$, kesetaraan $(75,66 \%)$, dan kerjasama $(80,44 \%)$, secara signifikan. Provinsi NTT memeroleh nilai tertinggi dalam hal kerukunan umat beragama, peringkat kedua adalah Bali dan ketiga Maluku (Balitbang Agama, 2016:63). kelompok-kelompokagamayangberbeda. Fokus perhatian riset ini bukan hanya pada bagaimana mengelola keragaman, meskipun jelas aspek ini sangat penting, tapi juga konteks menyeluruh yang terkait dengan permasalahanpermasalahan implementasi kebijakankebijakan keagamaan yang pada satu sisi, pemerintah telah mengatur jaminan kebebasan beragama, pendirian rumah ibadah dan lain-lain. Namun pada sisi lain, kebijakan tersebut kerap menimbulkan konflik keagamaan di berbagai daerah. Riset ini ingin menemukan lessons learned yang bisa dijadikan contoh di tempattempat lain. Riset ini ingin menemukan faktor-faktor deteminan yang menjadi penyangga dalam relasi yang harmonis dan juga faktor-faktor yang bisa memicu konflik antarumat beragama di Bali. Terkait dengan persoalan regulasi yang dinilai kerap menimbulkan konflik, riset ini juga ingin mengetahui bagaimana tokoh-tokoh agama di Bali menyikapi berbagai peraturan keagamaan yang dianggap sering menimbulkan konflik.

Hasil riset ini bertujuan untuk mendeskripsikan berbagai faktor yang menjadi penyangga kerukunan antarumat beragama dan juga selubung konflik dalam masyarakat Bali yang majemuk. Dengan demikian, hasil penelitian ini diharapkan dapat memberi informasi dan melengkapi hasil-hasil kajian tentang persoalan kerukunan umat beragama di masyarakat. kajian ini sangat penting diketahui masyarakat luas dan pengambil kebijakan untuk mengatasi berbagai konflik agama yang terjadi di Indonesia, serta bagaimana menciptakan kerukunan antarumat beragama dan pemeliharaannya. Dari keduanya dapat diambil pelajaran dalam penguatan kerukunan antarumat beragama. Hasil kajian ini dapat ditindak lanjuti penyusunan model-model pembinaan kerukunan antarumat beragama. Bagi pemuka agama, pimpinan majelis agama serta FKUB dan sejenisnya, dapat 
mereplikasikannya pada daerah lain sesuai sifat dan kondisinya

\section{METODE}

Penelitian tergolong pada jenis penelitian kualitatif. Penelitian dilakukan dengan mengambil lokasi di Denpasar, Bali, pada tahun 2016. Pengumpulan data dilakukan dengan wawancara mendalam, Diskusi Kelompok Terfokus (DKT), dan dokumentasi untuk mengambil data-data tertulis yang mendukung fokus penelitian. Data yang terkumpul dianalisis melalui data reduction, data display, dan conclusion drawing/verifying (Denzin dan Lincoln, 1994). Telaah dokumen dilakukan untuk mendapatkan informasi-informasi terkait dengan persoalan penelitian yang berasal dari dokumen-dokumen tertulis, baik laporan-laporan dari lembaga pemerintah maupun lainnya, dan perda (peraturan daerah) yang diterbit oleh pemerintah daerah yang relevan dengan penelitian ini. Adapun Focus Group Discussion (FGD) ini dilaksanakan di badan Diklat Provinsi Bali yang diikuti 10 orang tokoh masyarakat lintas agama. FGD ini dilakukan untuk mengkonfirmasi datadata yang telah diperoleh, dan menggali informasi-informasi baru yang belum diperoleh dalam teknik lainnya.

\section{HASIL DAN PEMBAHASAN}

\section{Bali dalam Keragaman Budaya dan Agama}

Provinsi Bali secara geografis berupa sebuah pulau yang di bagian tengah pulau berbentuk bentangan pegunungan yang memanjang dari Barat ke Timur, berupa dua gunung berapi dan pegunungan tidak berapi. Kedua gunung berapi dimaksud yakni Gunung Agung dan Gunung Batur dengan ketinggian masing-masing 3.140 meter dan 1.717 meter. Sedangkan pegunungan yang tidak berapi yaitu: Gunung Merbuk berketinggian 1.386 meter, Gunung Patas 1.414 meter dan Gunung Seraya 1.174 meter di atas permukaan laut. Bentangan pegunungan di atas secara geografis membagi wilayah Provinsi Bali menjadi dua bagian, yaitu Bali Utara dengan dataran rendah yang sempit dan kurang landai dan Bali Selatan dengan dataran rendah yang luas dan landai. Selain pegunungan, keadaan alamnya diwarnai oleh adanya 4 buah danau yaitu: Danau Beratan, Danau Buyan, Danau Tamblingan dan Danau Batur. Danaudanau ini merupakan aset pariwisata, selain pantai Sanur dan Kuta yang terkenal dengan keindahannya. Kondisi alamnya juga didukung oleh kawasan hutan di daerah pegunungan yang membentang dari Barat sampai bagian Timur wilayah Bali, yang berfungsi sebagai pelindung erosi dan banjir (Pemerintah Provinsi Bali, Badan Perencanaan Pembangunan, 2011, hal. A- 1)

Luas wilayah Provinsi Bali mencapai 5.636,66 $\mathrm{km} 2$ atau 0,29 \% dari luas seluruh wilayah Indonesia. Wilayahnya selain terdiri atas satu pulau utama yaitu P. Bali, terdapat pulau-pulau kecil seperti: P. Nusa Penida, P. Nusa Ceningan, P. Nusa Lembongan dan P. Menjangan. Secara administratif Provinsi Bali terbagi menjadi 8 kabupaten, 1 kota, 57 kecamatan, 715 desa/kelurahan, 1.482 Desa Pekraman dan 3.625 Banjar Pekraman. Luas wilayah masing-masing kabupaten beragam. Kabupaten Buleleng memiliki wilayah paling luas, yakni 1.365,88 km2, kemudian Kabupaten Jembrana 841,80 km2, Kabupaten Karangasem 839,54 km2 dan Kabupaten Tabanan 839,33 km2 (Pemerintah Provinsi Bali, Badan Perencanaan Pembangunan, 2011, hal. A- 1).

Bali sebagai daerah pariwisata, menjadi harapan banyak orang di luar pulau Bali untuk mengadu nasib dan mencari peruntungan ekonomi. Proses 
migrasi penduduk menyebabkan provinsi Bali terdiri dari masyarakat dengan berbagai latar belakang suku dan etnis. Namun demikian, etnis Bali yang merupakan penduduk asli, masih menempati posisi jumlah terbesar.

Gambar 1

Komposisi penduduk di Provinsi Bali

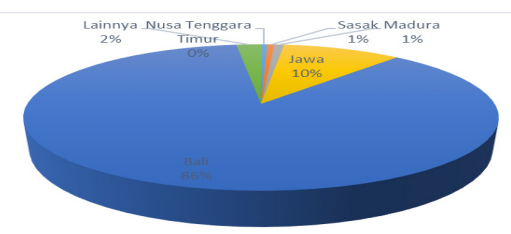

Diolah dari data BPS 2010

Berdasarkan data Sensus Penduduk Tahun 2010 di atas, Kehidupan masyarakat di Bali terdiri dari 3 (tiga) etnis terbesar yakni Bali, Jawa dan Madura ditambah suku-suku lainnya yang hidup secara berdampingan dan harmonis. Mayoritas penduduk adalah etnis Bali, tercatat sebanyak 3336065 jiwa atau sekitar 86\%. Selebihnya dari Jawa, Madura, Batak, dan lainnya. Selain suku-suku tersebut juga ada pendatang dari berbagai daerah lainnya seperti Sumatera, Sulawesi, Ambon dan sebagainya. Sementara itu, data Dinas Kependudukan dan Catatan Sipil provinsi Bali tahun 2014 menunjukkan populasi penduduk di provinsi Bali kini telah mencapai 4,022,576 Jiwa.

Komposisi masyarakat Bali yang semakin plural dan multikultural merupakan modal dasar untuk membangun pola keberagamaan yang akan membawa sebuah tatanan sosial yang dinamis. Meskipun terdiri dari berbagai macam etnis maupun agama, namun kerukunan antarumat beragama di Bali tetap terjaga. Dalam kaitan ini, Puja Mandala dijadikan sebagai simbol atau perwujudan dari toleransi antar umat beragama tersebut ${ }^{5}$. Keberadaan

5 Wawancara Pdt. Sudira Husada, 20 Mei 2016 bangunan suci itu menunjukkan interaksi sosial (persahabatan) antara penganut agama terjalin dengan baik dan kondusif. Puja Mandala yang artinya tempat pemujaan, merupakan tempat peribadatan 5 agama yang diakui di Indonesia yaitu Islam, Kristen Katholik, Kristen Protestan, Hindu, Buddha di kawasan Nusa Dua Bali. Kelima tempat ibadah tersebut letaknya berdampingan, tidak ada batas pemisah, mempunyai satu halaman dan tinggi bangunan yang sama.

\section{Toleransi Antarumat Beragama di Bali: Sebuah Warisan Sejarah}

Dalam wacana keagamaan, khususnya menyangkut status dan hubungan antarumat beragama di Indonesia, sangat sering kita menemukan penggunaan istilah "mayoritas" dan "minoritas" (atau besar dan kecil dalam jumlah angka). Untuk konteks Indonesia, umat Islam adalah umat yang mayoritas dibanding umat beragama lainnya. Islam dianut oleh $87.18 \%$ penduduk, Kristen dianut oleh $6.96 \%$, katholik dianut oleh $2.91 \%$, Hindu dianut oleh $1.69 \%$, Budha dianut oleh $0.72 \%$ dan Khong $\mathrm{Hu} \mathrm{Chu}$ dianut oleh $0.05 \%$ (Naim dan Hendri Saputra, 2010:7). Dari jumlah ini jelas umat Islam adalah terbesar dalam jumlahnya. Meski data tersebut mengungkapkan bahwa penduduk beragama Islam merupakan mayoritas secara nasional, namun tidak demikian dalam sebaran perpropinsi atau kabupaten/kota. Agama-agama tertentu lainnya menunjukkan jumlah mayoritas penduduk di propinsi tertentu seperti serta Kristen di Sulawesi Utara, dan Papua. Komposisi jumlah penduduk Islam dan Kristen cukup berimbang di Maluku. Sedangkan penduduk di Bali, mayoritas adalah pemeluk agama Hindu dengan jumlah yang terbesar di Nusantara.

\begin{tabular}{l|l} 
Jurnal Multikultural \& Multireligius Vol. 17 & No. 1
\end{tabular} 
Table I

Komposisi penduduk di Bali berdasarkan agama

\begin{tabular}{|c|c|c|}
\hline No & Agama & Jumlah \\
\hline 1 & Hindu & $3,510,752$ \\
\hline 2 & Islam & 396,980 \\
\hline 3 & Budha & 29,791 \\
\hline 4 & Kristen & 47,048 \\
\hline 5 & Katolik & 37,564 \\
\hline 6 & Konghucu & 441 \\
\hline \multicolumn{2}{|c|}{ JUMLAH } & $4,022,576$ \\
\hline
\end{tabular}

Sumber: Kementrian Agama Provinsi Bali, 2016

Persoalan yang sering menjadi isu sensitif dan krusial dalam hubungan minoritas dan mayoritas adalah relasi antarkelompok tersebut dalam bingkai kerukunan antarumat beragama. Kesetiaan umat terhadap agamanya secara negatif cenderung melahirkan ideologi eksklusif yang dapat melahirkan konflik antarumat beragama.

Namun, tidak demikian halnya yang terjadi di Bali, keharmonisan antarumat beragama telah berlangsung lama dan tetap terjaga hingga saat ini. Hal ini tidak terlepas dari peran sejarah, di mana Islam telah tercatat sejak 1460 pada masa kerajaan Gegel di Klungkung. Cikal-bakal Muslim di Klungkung adalah para pengawal Dalem Kerajaan Majapahit yang berjumlah 40 orang pada masa pemerintahan Dalem Ketut Ngelisir (Raja Gelgel I). Di Tabanan sendiri peran Islam telah ada sejak awal abad 19. Komunitas Muslim di Bali memang punya sejarah yang erat dengan para penguasa dan masyarakat Bali di zaman dulu, mereka (komunitas muslim) dilabeli dengan nyama selam atau saudara Islam.

Interaksi Nyama Bali dan Nyama Selam yang sudah terjadi sejak beberapa abad, memungkinkan mereka saling mempengaruhi baik dari segi sosial maupun budaya. Hal ini dibuktikan dengan berbagai peminjaman identitas etnik di kampung muslim di desa Pegayaman, dusun Saren Jawa desa Budakeling yang menggunakan nama depan khas Bali seperti Wayan, Putu, Made, Nengah, Komang, Nyoman, Ketut. Pengunaan bahasa Bali, saling kunjungi dalam acara adat, ritual, dan acara penting dalam kehidupan sehari-hari dapat memperkuat integrasi, di kalangan umat muslim di daerah-daerah seperti Saren Jawa, Desa Gelgel, dan Kepaon (Pageh, et.al., 2013).

Keharmonisan antarumat beragama di Bali juga terwujud akibat adanya tataran nilai dan tataran sosial budaya yang diterapkan secara konsisten oleh Hindu dan Muslim. Seperti diperlihatkan Basyir (2013) Dari sisi tataran nilai, Bali memiliki alam yang indah, dan keindahan ini terpelihara karena Bali menerapkan Tri Hitakarana dan Tat Twam Asi, Yama Niyama Brata. Sedangkan dari sisi tataran sosial budaya, Bali memiliki kultur terbuka namun tetap mampu melestarikan budaya nyama braya, segilik seguluk, beda paksi bina paksa. Dua nilai ke-Bali-an itu diterapkan oleh komunitas berbeda tetapi secara bersama. Walhasil komunitas Bali di masa lampau, mampu menciptakan keharmonisan. Logika itulah yang mendasari hubungan yang harmonis antara umat Islam dan umat Hindu di Bali. Namun, konteks sosial politik dan ekonomi telah mendistorsi keharmonisan itu. Bahkan, peristiwa Bom Bali akhirnya memperparah problem toleransi antarumat beragama di Bali. Tradisi Nyama Braya telah mengalami cobaan yang dahsyat dengan peristiwa Bom Bali. Pada masa ini, hubungan Islam dan Hindu yang selama ini terjalin dengan baik mulai terusik. Peristiwa ini, menyebabkan terjadinya ketegangan antara Muslim dengan Hindu. Komunitas Muslim di Bali menjadi sasaran kecurigaan, dan keamanan di Bali mulai diperketat kembali. Seperti dituturkan 
informan", "sebelum bom Bali 2002, boleh dikata, umat Islam dan umat Hindu itu saling bahu membahu, banyak orangorang Islam yang dari Jawa punya bapak angkat orang Hindu di sini. Dahulu, Posisi umat Islam punya kedudukan terhormat di sini. Antara umat Islam dan umat Hindu terjalin hubungan yang sangat baik, seperti keluarga sendiri. Mereka (penduduk lokal) memberi tempat kepada pendatang. Namun, peristiwa peristiwa Bom Bali I dan II mengubah segalanya. Peristiwa itu benar-benar menyakitkan bagi orang Bali, sehingga kita pun (umat Islam) juga terusik dan menjadi yang dicurigai. Umat Islam selalu menjadi yang dipojokkan".

Pasca peristiwa Bom Bali, tokohtokoh agama yang tergabung dalam FKUB Bali memunculkan gerakan-gerakan multikulturalisme. Mereka lebih sering bertemu dan berdialog untuk menyikapi masalah tersebut. Pemimpin-pemimpin agama kemudian sepakat untuk samasama menjaga dan menahan diri dengan tujuan agar masyarakat tidak saling tuding yang akan berujung pada konflik horizontal. Seperti dituturkan informan, "antara umat Islam dan umat Hindu di Bali sepakat bahwa peristiwa Bom Bali tidak boleh dikaitkan dengan etnis, agama, dan kepercayaan apapun"7. Melalui kerja keras tokoh agama, pemerintah, dan juga masyarakat Bali, akhirnya kehidupan keberagamaan masyarakat di Bali berangsur-angsur pulih dan kembali hidup harmonis sampai sekarang. Meski begitu, riak-riak konflik seperti adanya konflik-konflik warga, dan konflik desa adat yang bersifat lokal, terkadang masih tetap ada. Kesemuanya itu memberikan warna tersendiri terhadap bangunan kerukunan antarumat beragama di Bali.

\footnotetext{
6 Wawancara Ustaz Fauzi, Tokoh Muslim di Bali, 17 Mei 2016

7 Wawancara Ida Pangelingsir Agung Putra Sukahet I, FKUB Propinsi Bali, 22 Mei 2016. Pernyataan yang sama juga dikemukakan oleh beberapa informan lainnya, H. Mustofa (Tokoh Muslim), Pdt Sudira Husada (Tokoh Kristen), dan Ida Bagus Sedhawa (Tokoh Hindu)
}

\section{Kearifan Lokal: Modal Kultural Kerukunan Antarumat Beragama di Bali}

Dalam banyak hal, sulit membedakan mana yang adat dan mana yang menjadi bagian dari tradisi Hindu. Nilai-nilai budaya dan agama Hindu ini, terintegrasi dalam tata kehidupan masyarakat Bali yang memang mayoritas beragama Hindu. Nilai-nilai tersebut melekat pada tradisi, ritual, upacara, yang masih dipertahankan hingga saat ini. Termasuk juga tata kelola pemerintahan modern yang dikompromikan dengan tata kelola pemerintahan adat.

Masyarakat Bali memiliki kedewasaan dalam memahami realitas masyarakatnya yang majemuk ${ }^{8}$. Mereka memiliki mekanisme kultural untuk menjaga kerukunan dalam keragaman baik etnik maupun agama, Ia lazim disebut kearifan lokal (local wisdom), sebuah kebijaksanaan yang ditransmisikan dari satu generasi ke generasi berikutnya. Faktor instrinsik budaya ini sangat mendukung terciptanya kerukunan antarumat beragama di Bali.

Masyarakat Bali dikenal memiliki nilai-nilai budaya -budaya dalam arti adat maupun agama- seperti Menyama Braya (persaudaraan), Tat Twam Asi, Yama Niyama Brata (aku adalah engkau, engkau adalah aku); Tri Hita Karana (hubungan manusia dengan: Tuhan, antar manusia dan dengan alam); dan Karma Pala (segala sesuatu yang dilakukan akan ada balasannya). ${ }^{9}$ Nilai-nilai budaya tersebut terpatri kuat dalam kehidupan sosioreligius masyarakatnya.

8 Wawancara dengan I Wayan Lastra, Kabimmas Hindu Kementrian Agama Propinsi Bali, 22 Mei 2016. Pernyataan yang sama juga dikemukakan oleh $\mathrm{H}$. Mustofa, FKUB Kota Denpasar dan I Putu Astawa dari PHDI provinsi Bali.

9 Wawancara Ida Bagus Sedhawa, Kepala Badan Diklat Provinsi Bali, 20 Mei 2016.

\begin{tabular}{l|l} 
Jurnal Multikultural \& Multireligius Vol. 17 & No.
\end{tabular} 
Menyama Braya : Persaudaraan dalam Perbedaan

Budaya menyama braya merupakan salah satu budaya yang meneguhkan toleransi antarumat beragama di Bali (Pageh, et.al., 2013). Kearifan lokal (local wisdom) Menyama braya dipahami dan diyakini secara luas sebagai sebuah sarana yang efektif dalam menjaga integrasi sosial. Menurut Pageh, et.al., (2013) Menyama braya merupakan modal kultural yang strategis bagi terciptanya integrasi sosial. Menyama braya merupakan suatu cara hidup yang memahami bahwa semua manusia adalah bersaudara atau cara hidup yang memperlakukan semua manusia sebagai saudara. Cara hidup ini, menurut Suarka (2005: 40-41), dimaksudkan untuk menjaga keharmonisan hidup di tengah masyarakat yang berbeda khususnya antara Bali (Hindu) dengan Budha dan Islam. Selanjutnya dari budaya menyama braya ini lahirlah sebutan identitas: nyama Bali (saudara Bali), nyama Cina (saudara cina), nyama selam (saudara Islam), nyama Buda (saudara Budha) dan kemudian nyama Kristen (saudara Kristen) (Setia 2002: 89; Soethama 2006: 2005). Bahkan, dalam konsepsi hari raya di Bali pun kemudian dikenal adanya istilah Galungan Cina, untuk menyambut hari raya imlek, galungan Selam untuk menyambut hari raya Idul Fitri (Wijana, 2003: 59). Dengan perkataan lain, bahwa dengan adanya sebutan nyama (Cina, Islam, Bali, Budha dan Kristen) dalam pergaulan/interaksi masyarakat Bali menjadi satu bukti bahwa sejak dini masyarakat Bali sadar, bahwa nyama atau braya tidak dipahami sebatas tunggal darah atau se-klen, seagama, seetnis dan sekultur namun mereka memahami walaupun tidak tunggal darah atau seklen, berbeda dalam keyakinan/agama, etnis dan kultur sesungguhnya mereka semua adalah bersaudara. Adanya perbedaanperbedaan (agama, keyakinan, suku, bahasa, kultur dan warna kulit) tidak membuat tali persaudaraan terputus, justru menjadi bingkai atau pelindung dalam kerukunan hidup atau integrasi masyarakat dari ancaman pertikaian dan disintegrasi (Damayana, 2011).

Menyama braya bagi masyarakat Bali selain sebagai kearifan lokal yang menjadi landasan moral dalam membangun relasi sosial, juga merupakan kekayaan utama dalam hidup dan sebagai jalan untuk menggapai kedamaian dan keharmonisan. Budaya menyama braya dalam fungsinya merupakan proses saling keterikatan dan dapat dikembangkan berdasarkan pandangan bahwa pada hakikatnya tiap umat beragama dan semua umat manusia adalah bersaudara. Tuhan Yang Maha Esa menciptakan manusia yang beragam keyakinan, warna kulit dan bahasa untuk saling mengenal, bergaul dan tolong menolong dalam kebaikan dan ketaqwaan, hormat menghormati dalam kerukunan hidup antarumat beragama (Puja Media 2002: iv).

"Tradisi Ngejot": Simbol Kerukunan Antarumat Beragama

Ngejot bagi Umat Hindu di Bali adalah memberikan makanan kepada para tetangga yang dilaksanakan masyarakat Hindu Bali. Ini adalah sebuah tradisi unik turun temurun dari masyarakat Pulau Dewata Bali. Ngejot juga dapat diasosiasikan berbagi makanan atau jotan kepada para tetangga dan sanak keluarga. Bagi umat Hindu tradisi ini di gelar biasanya pada Hari Raya Galungan, Kuningan dan Hari Raya Nyepi. Biasanya makanan yang diberikan biasanya makanan siap saji, kue serta buah-buahan diantaranya berupa urap, lawar dan daging babi. Tradisi ini menjadi simbol kemesraan dan tali kasih persaudaraan umat Hindu di Bali. 
Umat Islam yang ada di Bali juga mempunyai tradisi ngejot ke pada umat Hindu. Tradisi dan budaya itu hingga sekarang masih tetap lestari baik di Desa maupun di perkotaan di Bali. Tradisi Ngejot bagi komunitas muslim menunjukan adanya kekerabatan begitu akrab dengan umat Hindu di Bali. Seperti yang ada Kepaon di Denpasar, dan wilayah lainnya seperti Desa Pegayaman Buleleng, Desa Budakeling Karangasem, Desa Petang Badung, dan Desa Loloan di Jembrana.

Menurut Ketua Umum Majelis Ulama Indonesia (MUI) Bali, H M Taufik Asadi, S. Ag, Tradisi Ngejot hingga sekarang masih tetap lestari, baik di desa maupun perkotaan di Pulau Dewata. tradisi ini mencerminkan keakraban dalam kehidupan sehari-hari, yang secara tidak langsung memberikan dampak positif dalam memantapkan kerukunan hidup beragama yang telah diwujuudkan selama ini (Astawa, 2015).

\section{Tat Twam Asi: Toleransi Tanpa Pembedaan}

Konsep kunci lainnya yang dipegang teguh oleh umat Hindu sebagai pedoman dalam meneguhkan kerukunan antarumat beragama adalah Tat Twam Asi dan Yama Niyama Brata. Tat Twam Asi yang berarti aku adalah engkau, sedang Yama Niyama Brata yang berarti engkau adalah aku. ajaran Tat Twam Asi menekankan pada toleransi tanpa menonjolkan perbedaan. Dalam ajaran ini juga terkandung nilai solidaritas yang tinggi serta toleransi yang menimbulkan rasa persaudaraan dan kerukunan hidup antar sesama manusia dan mewarnai tata susila masyarakat Bali, seperti: Tresna Asih, Anresangsia, Catur Paramitha, Tri Kaya Parisudha, dan Yadnya (Setia, 1993: 58-59). Dengan demikian, hakikat Tat Twam Asi dan Yama Niyama Brata pada akhirnya bermuara dari kasih sayang yang diaktualisasikan ke dalam bentuk sikap egaliter yang memandang segala makhluk adalah sama. Nilai-nilai kerbersamaan, kerjasama, gotong-royong itu dijunjung tinggi, seperti tercermin dalam konsepsi sagilik saguluk, salunglung sabayantaka, paras parossarpanaya, beriuksaguluk. Konsepsi ini mengandung nilai solidaritas yang tinggi dalam suka dan duka, baik dan buruk ditanggung bersama. Bersama-sama dalam kegiatan baik suka maupun duka (Titib, 2012; Suastika, 2005:16-18). Sementara, konsepsi Karmaphala mengandung nilai sebab akibat karena perbuatan yang baik akan selalu menghasilkan pahala yang baik dan demikian sebaliknya. Konsepsi ini merupakan landasan bagi pengendalian diri dan dasar penting bagi pembinaan moral dalam berbagai segi kehidupan. (Titib, 2012).

Ragam kearifan lokal ini berperan dalam menjaga harmoni antar masyarakat. Mereka berperan dalam upaya pencegahan maupun upaya resolusi konflik. Dalam konteks ini, Haba (2008) melihat lima peran vital kearifan lokal sebagai media resolusi konflik keagamaan:pertama, kearifanlokal sebagai penanda identitas sebuah komunitas. Identitas tersebut menunjukkan bahwa komunitas tersebut memiliki budaya perdamaian yang berarti menunjukkan komunitas tersebut merupakan komunitas yang beradab. Kedua, kearifan lokal sendiri menyediakan adanya aspek kohesif berupa elemen perekat lintas agama, lintas warga, dan kepercayaan. Dalam konteks ini, kearifan lokal dapat diartikan sebagai ruang maupun arena dialogis untuk melunturkan segala jenis esklusivitas politik identitas yang melekat di antara berbagai kelompok. Adanya upaya menjembatani berbagai lintas kepentingan tersebut adalah upaya untuk membangun inklusivitas dalam meredam potensi konflik yang lebih besar lagi. Ketiga, berbeda halnya dengan penerapan hukum positif sebagai media resolusi konflik yang selama ini jamak dilakukan oleh para penegak hukum kita yang kesannya "memaksa". Kearifan 
lokal sebagai bagian dari resolusi konflik alternatif justru lebih ke arah mengajak semua pihak untuk berunding dengan memanfaatkan kedekatan emosi maupun kultural. Keempat, kearifan lokal memberi warna kebersamaan bagi sebuah komunitas dan dapat berfungsi mendorong terbangunnya kebersamaan, apresiasi, sekaligus sebagai sebuah mekanisme bersama menepis berbagai kemungkinan yang dapat meredusir, bahkan merusak solidaritas komunal, yang dipercaya berasal dan tumbuh di atas kesadaran bersama, dari sebuah komunitas yang terintegrasi. Kelima, Kearifan lokal akan mengubah pola pikir dan hubungan timbal balik individu dan kelompok, dengan meletakkan di atas kebudayaan yang dimiliki. Maka bisa dikatakan bahwa kearifan lokal merupakan bentuk sintesa dari unsur sosio-kultural dan sosio-keagamaan yang tujuannya adalah merekatakan kembali hubungan antar sesama masyarakat yang tereduksi perebutan kepentingan politik maupun ekonomi.

Bagi masyarakat Bali, toleransi antarumat beragama menjadi persoalan yang sudah selesai. ${ }^{10}$ Sebagai contoh, ketika pelaksanaan hari raya Nyepi ${ }^{11}$ bersamaan dengan hari Jum'at. Misalnya, pada tahun 2008, hari raya Nyepi jatuh pada hari Jum'at. Berdasar surat edaran Gubernur Bali No. 003.2/15.743/ Dishub Tahun 2008, Pemerintah Provinsi Bali, dalam hal ini Gubernur

\footnotetext{
19 Mei 2016

10 Wawancara H. Mustofa, FKUB Kota Denpasar,

11 Nyepi (hari raya Nyepi) merupakan salah satu hari besar umat Hindu khususnya di Bali, untuk merayakan tahun baru. Çaka. Pada hari itu, umat Hindu melaksanakan suatu ritual dengan apa yang disebut Catur Brata Penyepian, yaitu amati mekarya (tidak beraktifitas dalam melaksanakan pekerjaan), amati geni (tidak memasak/berpuasa), amati lelungan (tidak bepergian) dan amati lelanguan (tidak menikmati hiburan/ menyepi). Selama pelaksanaan ritual Nyepi, seluruh aktifitas kegiatan dihentikan dalam waktu 24 jam (dari jam 06.00 hingga jam yang sama pada hari berikutnya). Kendaraan tidak boleh keluar (kecuali ambulan), lampu dimatikan, tidak boleh keluar rumah, tidak ada kapal laut yang bersandar untuk masuk ke Bali, tidak ada pesawat yang boleh mendarat di bandara dan tidak boleh ada penerangan (sinar) di malam hari.
}

Bali mengeluarkan himbauan tentang pelaksanaan Shalat Jum'at. Salah satu isi himbauan adalah kebolehan umat Islam melaksanakan sholat Jum'at di Masjid dengan beberapa syarat antara lain; tidak boleh menggunakan kendaraan bermotor untuk pergi ke masjid, pengeras suara luar tidak diperbolehkan. Wujud teknis penyelengaraan aturan ini kemudian disosialisasikan dan dipraktekkan sedemikian rupa. Artinya tidak menjadi persoalan serius bagi pengurus takmir musholla/masjid. ${ }^{12}$

\section{Agen-agen Kerukunan: Modal Struktural yang Memperkuat Kerukunan antarumat Beragama di Bali}

Terciptanya toleransi dan kerukunan antarumat beragama di Bali, selain dipengaruhi oleh faktor keteladanan sejarah dan modal kultural berupa kearifan lokal, juga diperkuat dengan modal struktural berupa agenagen kerukunan seperti lembagalembaga penjaga tradisi dan FKUB yang saling bahu membahu dalam menjaga dan menciptakan kerukunan.

\section{Desa Pakraman dan PHDI sebagai Lembaga Penjaga Tradisi}

Bali, memang berbeda dengan wilayah-wilayah lain di Indonesia. Di wilayah ini, selain terdapat pemerintahan desa/kelurahan (desa dinas) terdapat pula desa adat (Desa Pakraman $)^{13}$. Istilah Pakraman

12Wawancara Ida Pangelingsir Agung Putra Sukahet 1, FKUB Provinsi Bali, 22 Mei 2016

13 Misal, di Kecamatan Denpasar Selatan selain terdapat 10 desa dinas/kelurahan, terdapat pula 11 desa adat, 106 banjar dinas dan 90 banjar adat. Di Denpasar Timur selain 11 desa dinas/kelurahan terdapat pula 12 desa adat, 87 banjar dinas dan 97 banjar adat. Di Denpasar Barat selain terdapat 11 desa dinas/kelurahan terdapat pula 2 desa adat, 112 banjar dinas dan 106 banjar adat. Sedangkan di Denpasar Utara selain terdapat 11 desa dinas/kelurahan terdapat pula 10 desa adat, 102 banjar dinas dan 99 banjar adat. Dengan demikian di wilayah Kota Denpasar selain secara nasional terdapat 43 
dipakai untuk menegaskan otentitas dan otonomi desa tradisional, karena kata adat, terlalu dianggap kolonial dan terlalu Islami (Schulte Nordholt 2010: 34). Desa Pakraman adalah kesatuan masyarakat Hukum Adat yang dijiwai oleh ajaran agama Hindu. Melaluinya diatur mengenai Parhyangan (hubungan vertikal dengan Tuhan), Pawongan (Hubungan horizontal antar warga), dan Palemahan (hubungan diagonal dengan lingkungan/wilayah). Desa Pakraman di Bali bertujuan untuk melestarikan khayangan tiga: Pura Puseh, Pura Desa dan Pura Dalem (Palguna 1998:103; Jean Counteau 2008: 30-31; Sudantra 2007: 2). Sebagai lembaga tradisional, Desa Pakraman berperan penting dalam menjaga tradisi. Hal ini dapat dicermati pada wewenang Desa Pakraman seperti yang diatur dalam Peraturan Daerah Propinsi Bali Nomor 3 Tahun 2001 tentang Desa Pakraman. Dalam aturan ini tersirat bahwa fungsi Desa Pakraman adalah basis bagi pengembangan dan pemertahanan adat dan Agama Hindu (Geertz, 1977; Atmadja, 1998). Dalam melaksanakan tugas dan kewenangan, Desa Pakraman berpedoman pada awig-awig ${ }^{14}$ yang merupakan pedoman

pemerintahan desa/kelurahan yang disebut desa dinas, terdapat pemerintahan adat yang jenis dan jumlahnya jauh lebih banyak dibanding dengan pemerintahan desa/ kelurahan. Jenis-jenis pemerintahan adat dimaksud yaitu: desa adat 35 buah, banjar dinas 407 buah dan banjar adat 392 buah (Badan Pusat Statistik Kota Denpasar, 2011, hal. 17). Sebagian besar yakni sekitar 10.136 ha wilayah Kota Denpasar terdiri atas tanah kering, sekitar 2.632 ha berupa persawahan dan selebihnya terdiri atas antara lain tambak, kolam, tebat dan empang (Badan Pusat Statistik Kota Denpasar, 2011, hal.1)

14 Awig-awig memegang peranan sangat penting dalam mengatur tata kehidupan masyarakat Bali, baik di bidang agama/kebudayaan maupun dalam bidang sosial ekonomi. Masyarakat Bali sampai saat ini masih menjunjung tinggi dan menghormati awig-awig desa pakraman dan menaati serta mematuhi ketentuanketentuanya sehingga awig-awig desa pakraman dalam pembinaan hukum nasional harus diperhitungkan. Awig-awig pada umumnya tidak tertulis, sedangkan yang ditulis pada zaman dahulu disebut pengeling-eling atau tunggul (catatan). Dalam Peraturan Daerah No. 3 Tahun 2001 pasal 1 huruf (11), awig-awig adalah aturan yang dasar dari Desa Pakraman dalam pemerintahannya. Desa Pakraman mempunyai kewenangan untuk mengurus dan menyelenggarakan kehidupan rumah tangganya sendiri yang bersifat sosial religius, sosial ekonomi, dan sosial kemasyarakatan. Desa Pakraman mempunyai tiga macam kekuasaan yakni: (a) kekuasaan untuk menetapkan aturan, (b) kekuasaan untuk menyelenggarakan kehidupan organisasi yang bersifat sosial religius, (c) kekuasaan untuk menyelesaiakan sengketa-sengketa (Widnyana dalam Astara, 2010).

Desa Pakraman membina penduduk pendatang dalam kaitannya dengan tri hita karana sebagai kearifan lokal di Bali yang tertuang dalam pasal 13, Peraturan Daerah Bali No 3 Tahun 2001 tentang Desa Pakraman yang berbunyi "Desa adat dapat berpartisipasi aktif dalam upaya pembinaan terhadap penduduk pendatang dalam kaitannya dengan tri hita karana sehingga terwujud hubungan yang harmonis. Pasal 3 ayat (2) Perda No.3 Tahun 2001 dalam hal ini yang menjadi krama desa adalah orang yang menjadi anggota desa menurut tata cara dan syarat yang diatur dalam awig-awig desa. Wewenang Desa Pakraman adalah sebagai berikut: (a) menyelesaikan sengketa adat dan agama dalam lingkungan wilayahnya dengan tetap membina kerukunan dan toleransi antarkrama desa sesuai dengan awig-awig dan adat kebiasaan setempat; (b) turut serta menetukan setiap keputusan dalam pelaksanaan

dibuat oleh krama dan atau krama banjar pakraman yang dipakai sebagai pedoman dalam pelaksanaan tri hita karana sesuai dengan desa mawacara dan dharma agama di desa pakraman masing-masing. Lebih lanjut ditegaskan dalam perda tersebut yaitu pasal 7 ayat (1) bahwa setiap desa pakraman agar memiliki awig-awig yang tertulis; pasal 7 ayat (2) awig-awig desa pakraman tidak boleh bertentangan dengan dengan Pancasila, Undang-undang Dasar 1945, dan peraturan perundang-undangan yang berlaku (Sanjaya \& Sugiartha, 2013) . 
pembangunan yang ada di wilayahnya terutama yang berkaitan dengan trihita karana; (c) melaksanakan perbuatan hukum di dalam dan di luar desa adat (Sanjaya \& Sugiartha, 2013).

Terkaitdenganintegrasimasyarakat, multikulturalisme secara normatif telah tertuang dalam Peraturan Daerah No. 3 Tahun 2012 tentang Desa Pakraman dalam pasal 3 ayat (7): parahyangan dan tempat suci, baik bagi umat Hindu maupun umat lain yang ada dalam wilayah desa pakraman/banjar pakraman dijaga bersamasama oleh seluruh warga/krama dari desa pakraman/banjar pakraman atas dasar toleransi dan kerukunan serta saling menghormati dalam rangka membina rasa persatuan dan kesatuan masyarakat Indonesia.

Selain Desa Pakraman, lembaga lain yang juga berperan penting sebagai penjaga tradisi adalah Parisada Hindu Dharma Indonesia (PHDI). Secara struktural, legitimasi PHDI sangat kuat (Atmadja, 2010:53). PHDI adalah lembaga formal keumatan yang menghimpun para elite Agama Hindu yang memiliki modal kultural dan modal akademik yang andal. Dalam konteks ini, Desa Pakraman merupakan jaringan sosial PHDI di basis terbawah. Hubungan fungsional antara PHDI dan Desa Pakraman, memungkinkan mereka saling bertukar informasi, materi, dan finansial untuk menjaga kelangsungan hidup Agama Hindu dan aneka tradisi yang berkembang di wilayah ini. Selain Desa Pakraman dan PHDI, lembaga penjaga tradisi lainnya adalah Majelis Utama Desa Pakraman (tingkat propinsi), Majelis Madya Desa Pakraman (tingkat kabupaten), dan Forum Bendesa Pakraman. Semua lembaga ini merupakan sederatan lembaga formal yang tidak kalah pentingnya dalam menjaga tradisi baik secara terpisah maupun bersinergi (Atmadja, 2010:53).

\section{FKUB sebagai Agen Kerukunan Antarumat Beragama}

Jaringan komunikasi tokoh lintas agama di Bali sudah mulai dirintis jauh sebelum ada PBM Nomor 8/9 Tahun 2006. Atas inisiatif 5 majelis agama yaitu MUI, PHDI, Walubi, PGI dan keuskupan didirikanlah Forum Komunikasi Antar Umat (FKAU) yang bertujuan untuk membina hubungan antarumat beragama dan menjaga kebersamaan organisasi-organisasi keagamaan. Setelah disosialisasikannya PBM Nomor 8/9 Tahun 2006, FKAU berubah menjadi FKUB $^{15}$.

Pada intinya program-program kegiatan yang dilakukan oleh FKUB berupaya meredam ketidakrukunan yang terjadi di kalangan umat beragama, menyelesaikan perselisihan yang terjadi antarumat beragama dan pemeliharaan kerukunan umat beragama. FKUB berperan besar dalam merekatkan kerukunan antarumat beragama. Mereka menjadi penghubung antaragama atau tokoh agama dengan umatnya dalam membina kerukunan dan menyelesaikan persoalan-persoalan terkait dengan hubungan antarumat beragama. Sebagai contoh, pada menjelang perayaan Hari Nyepi, melalui FKUB dilakukan pertemuan yang diikuti para tokoh/ pimpinan lembaga agama, tokoh adat, unsur pemerintahan seperti: Polda, Korem, Kesbangpol, Kesra, Kanwil Kemenag dan Pemda untuk membahas dan membuat kesepakatan bahwa tidak saling mengganggu pada saat perayaan Hari Raya Nyepi, demikian pula ketika Hari Raya Nyepi bertepatan dengan hari Jum'at atau hari raya keagamaan lain ${ }^{16}$.

Dalam upaya mendorong dan mengembangkan harmonisasi kehidupan beragama di kalangan masyarakat, dilakukan sosialisasi Peraturan Bersama

15 Wawancara Ida Pangelingsir Agung Putra Sukahet I, 22 Mei 2016

2016

16 Wawancara H. Roihan, Sekum FKUB, 19 Mei 
Menteri Agama dan Menteri Dalam Negeri (PBM) Nomor 9 \& 8 Tahun 2006 kepada para tokoh masyarakat dan masyarakat, serta orientasi kerukunan kepada LSM. Apabila terjadi perselisihan terkait kerukunan umat beragama, pihak Kantor Wilayah Kementerian Agama Provinsi Bali, melakukan pendekatan dan memotivasi FKUB Provinsi Bali selaku katalisator yang anggota pengurusnya terdiri atas perwakilan dari umat masing-masing, untuk dapat memediasi pihak-pihak yang berselisih dalam upaya membantu menyelesaikan kasus perselisihan yang terjadi. Sebagai contoh, konflik berjubah agama yang muncul dalam beberapa kasus seperti yang terjadi di Desa Kauman, yakni perkelahian antarpemuda Hindu dan Muslim di sebuah warung makan. Perkelahian tersebut ternyata berakibat pada perkelahian massal antara komunitas Hindu dan Muslim. Setelah dibawa ke FKUB ternyata akar permasalahan terletak pada kriminalitas ${ }^{17}$.

Dalam konteks ini, besarnya peran tokoh dan pengaruhnya pada proses sosial di Indonesia antara lain karena masyarakat masih menganut budaya patrilineal (patriachi) dan patron-client. Tokoh-tokoh di masyarakat, baik tokoh agama maupun tokoh adat merupakan pihak yang dipandang memiliki status sosial tertentu yang baik berupa Ascribed Status (status yang tidak memperhatikan perbedaan jasmani atau rohani karena status tersebut diperoleh karena kelahiran atau hasil keturunan), maupun Achieved Status (status yang dicapai oleh seseorang melalui usaha-usaha yang disengaja, usaha dan kerja keras) yang dengan status tersebut dirinya memerankan diri sebagai tokoh (key person) (Patoni, 2007; 44). Mereka ini menjadi pemimpin-pemimpin informal yang suaranya didengar dengan kepatuhan oleh masyarakat. Pandangan masyarakat terhadap persoalan-persoalan

17 Wawancara H. Roihan, Sekum FKUB, 19 Mei di masyarakat, termasuk konflik sosial, sangat tergantung pandangan dari tokohtokoh tersebut. budaya paternalistik pada masyarakat Indonesia memungkinkan adanya teladan dari agen perubahan sosial, yakni para tokoh di masyarakat tersebut.

\section{Selubung Konflik}

\section{Rivalitas Ekonomi Berjubah Agama}

Agama bukanlah menjadi faktor utama dalam konflik anarkisme, namun hanya menjadi faktor pendukung ${ }^{18}$. Dalam berbagai kasus konflik yang mengatasnamakan agama seperti konflik di Kauman, agama justru terpolitisasi menjadi identitas konflik yang sebenarnya hanya menjadi topeng atas rivalitas perebutan sumber ekonomi, politik maupun birokrasi antar masyarakat ${ }^{19}$.

Pengembangan aneka bisnis pariwisata mengundang orang-orang dari luar Bali bermigrasi ke Bali untuk mencari nafkah. Mereka tersebar di berbagai kabupaten di Bali. Derasnya arus pendatang dari luar pulau Bali, dengan semangat usaha yang tinggi membuat mereka berhasil meraih peluang-peluang ekonomi baik di sektor formal maupun informal. Hal ini tentu saja menguatkan posisi ekonomi dan sosial komunitas non-Bali.

"Baksonisasi Pulau Bali", kelakar ini muncul di kalangan masyarakat Bali sebagai ekspresi simbolik ketersingkiran masyarakat lokal dalam ruang-ruang ekonomi. Keberadaan pendatang sering disebut sebagai faktor di balik berlangsungnya proses marginalisasi penduduk lokal. Para pendatang yang piawai melakukan adaptasi kultural dengan menjual bakso ayam, bukan bakso sapi (hewan yang disucikan oleh

18 Wawancara H. Mustofa, FKUB Kota Denpasar, 19 Mei 2016

19 Pendapat yang sama juga dikemukakan Ida Pangelingsir Agung Putra Sukahet 1, FKUB Provinsi Bali 
umat Hindu), menjadikan ketersingkiran penduduk lokal dalam ruang-ruang ekonomi semakin kuat. Mereka, yang oleh Atmadja (2010:360) disebut sebagai orang-orang yang berbudaya gemi (pintar mengatur keuangan) menjadi pedagang bakso yang sukses. Bahkan mereka bisa membeli tanah atau rumah. Hal inilah yang pada akhirnya menimbulkan lelucon dikalangan orang Bali, bahwa "orang Bali menjual tanah untuk membeli bakso, sebaliknya orang Jawa menjual bakso untuk membeli tanah" 20

Kelakar ini sebenarnya bukanlah kelakar ringan. Bila ditilik lebih lanjut, akibat perasaan tersingkirkan di wilayahnya sendiri, diperkuat dengan destrukturalisasi kelas $^{21}$ yang mereka lakukan, semakin menguatkan stereotype dan prasangka etnis bahwa orang Jawa telah merebut lahan ekonomi penduduk lokal. Hal inilah yang pada akhirnya mendorong mereka melakukan resistensi terhadap pedagang bakso. Isu bakso tikus dan formalin dibalut dengan etnisitas, distereotype-kan pada para penjual bakso yang berasal dari Jawa.

Seperti yang terjadi di Desa Pakraman Pau, Klungkung, resistensi dilakukan melalui gerakan boikot terhadap pedagang bakso. Hal ini tidak saja dilakukan secara individu, namun juga dengan melibatkan Desa Pakraman. Sebagaimana digambarkan oleh Atmadja (2010:382) desa ini membuat aturan berbentuk perarem yang melarang warganya membeli bakso pada pedagang bakso dari luar bali. Mereka yang menyalahi aturan, dikenai denda sebesar 40.000,-. Sedangkan pedagang bakso yang masuk ke wilayah Desa Pakraman Pau

20 Wawancara Ida Pangelingsir Agung Putra Sukahet 1, FKUB Provinsi Bali, 22 Mei 2016

21 Akibatkan perasaan "tersingkir" penduduk lokal karena peluang-peluang ekonomi yang banyak dinikmati pendatang, mendorong mereka melakukan destrukturalisasi dengan merombak sistem kelas. Hubungan strata yang semula berdimensi sosial (muwed tamiu) berubah menjadi hubungan yang berdimensi kelas, yakni warga tamiu (penduduk asli) berada pada kelas atas, sebaliknya warga muwed (pendatang) berada pada kelas bawah (Atmadja, 2010). dikenai denda Rp. 100.000,-. Meskipun Desa-desa Pakraman lainnya belum memberlakukan ketentuan tersebut, namun banyak pula yang memberikan imbauan untuk membatasi pembelian bakso.

"Merampas periuk nasi orang Bali", itulah anggapan penduduk lokal terhadap pendatang dari luar Bali. Hal ini tidak terlepas dari kenyataan bahwa banyaknya pendatang yang memasuki ranah nafkah yang diusahakan oleh orang Bali, mengakibatkan peluang nafkah orang Bali menjadi mengecil dan bahkan terpinggirkan (Dwipayana, 2003). ${ }^{22}$ Realitas ini menjadi semakin kompleks dengan adanya peristiwa Bom Bali I dan II. Pedagang bakso yang beretnis Jawa dan identitas agama Islam yang melekat pada dirinya semakin memperkuat resistensi masyarakat Bali terhadap pedagang bakso. Dalam keadaan yang demikian, perebutan ruang dan peluang ekonomi tidak dapat dihindarkan. Mengutip Nasikun (1992), kondisi yang penuh persaingan ini akan sangat mudah terjerumus dalam sebuah konflik sosial.

Selain itu, menjamurnya rumahrumah ibadah selama beberapa tahun belakangan ini juga telah melahirkan ketakutan kalangan akar rumput akan terkepung dan tergerusnya kultur dan budaya Hindu (Juniartha, 2005: 36). Ketakutan-ketakutan ini sebenarnya cukup beralasan, mengingat pertumbuhan rumah ibadah yang semakin lama semakin meningkat. Tempat ibadah umat Islam misalnya, jika pada tahun 2009 tempat ibadah umat Islam (Masjid dan Musholla) berjumlah

22 Kasus ketersingkiran masyarakat local diperlihatkan oleh temuan Erawan (Atmaja, 2010: 364) yang menunjukkan bahwa di kawasan Kuta Square, pemilik mal, toko, dan sejenisnya dikuasai oleh $70 \%$ pendatang. Gejala yang sama terlihat pula pada pasar Batukandik dan Pasar Anyar Sari di Kota Denpasar. Bahkan, sebagaimana disitir Harian Bali Post (Senin, 7 Februari 2005), 80\% dari asset pariwisata Bali dimiliki oleh orang di Luar Bali dan Luar Negri (dalam Atmadja, 2010: 349).

\begin{tabular}{l|l} 
HARMONI & Januari - Juni 2018
\end{tabular} 
472, maka pada tahun 2013, jumlah ini terus bertambah hingga berjumlah 709 buah (Kemenag Propinsi Bali, 2016).

Simbol-simbol keagamaan merupakan representasi masyarakat yang demikian kental sifat komunalnya. Melalui simbol-simbol inilah komunalisme agama sering menjadi pemandangan dalam relasi agama-agama (Azra, 1999:18). Semangat dan identitas komunalisme yang kuat, akan rentan memicu konflik yang mengatasnamakan agama. Jika persaingan antarkelompok sudah menohok etnisitas dan pergulatan identitas keagamaan, maka sang liyan cenderung dipersepsi sebagai orang asing (stranger), atau bahkan musuh. akar-akar kecurigaan ini akan tertanam sangat dalam, malah menjadi bagian melekat dalam pembentukan identitas keagamaan.

Persoalan lain yang juga menjadi masalah adalah banyak di antara pendatang yang kurang mendukung kearifan sosial yang menggariskan bahwa "dimana bumi dipijak, di sana langit dijunjung". Banyak di antara mereka yang justru mengembangkan sikap ekslusivisme individual maupun kelompok $^{23}$ dengan berbasiskan pada agama, sehingga hubungan sosial mereka dengan penduduk asli terbatas. Ditambah lagi, pendatang yang masuk ke Bali, selain mereka mencari nafkah, mereka juga membawa identitas kebudayaan etnisnya, termasuk didalamnya agama Islam. Mereka membentuk kantongkantong budaya yang bercorak segregasi sosial pada pemukiman mereka di daerah perkotaan. Jika jumlah mereka memenuhi persyaratan, sebagaimana yang ditetapkan dalam agama Islam, maka mereka berusaha membuat rumah ibadah. Pembangunan rumah-rumah ibadah oleh pendatang dimaknai sebagai ancaman terhadap identitas ke-Bali-an

23 Wawancara Ida Pangelingsir Agung Putra Sukahet 1, FKUB Provinsi Bali, 22 Mei 2016 mereka ${ }^{24}$. Masyarakat setempat melihat masyarakat pendatang sebagai saingan dan oleh karena itu mereka sikapi secara defensif dengan membangun kekuatan simbol-simbol budaya termasuk agama. Hal ini diperparah dengan pendatang yang notabene beragama Islam, tidak berbaur dengan masyarakat setempat ${ }^{25}$. Akibatnya, ikatan agama berkembang menjadi tersegregrasi dan masyarakat mengalami grouping berdasarkan afiliasi dan afinitas keimanan. Dalam konteks ini, politisasi identitas keagamaan sering berkelindan dengan konflik atas nama rivalitas ekonomi. Menguatnya etnosentrisme dan religiosentrisme atas dasar paham ke-kita-an dan ke-merekaan, dapat menjadi alat untuk merebutkan sumber-sumber ekonomi. Dalam kondisi ini, rivalitas agama harus disadari bisa menjadi supporting conflict. Bahkan bisa jadi, agama juga berperan besar sebagai tungku api dalam penciptaan konflik yang sejatinya hanya rivalitas ekonomi belaka. Meminjam gagasan Bakar dan Muhammad (2011:104), kecenderungan penguatan politik identitas berbasis agama bisa menjadi embrio kemunculan konflik kehidupan masyarakat multikultural dan multirelijius.

\section{Lemahnya Pengawalan Implementasi PBM No. 9 dan 8 Tahun 2006}

Kokohnya landasan konstitusi, modal kultural dan modal struktural yang dimiliki masyarakat Bali tidak dengan sendirinya menunjukkan bahwa kerukunan antar umat beragama di Bali telah tertunai dengan baik. Persoalan pemahaman terhadap pluralitas pemikiran merupakan tantangan utama yang harus dihadapi. Terkait dengan hal itu, kesadaran akan eksistensi pluralitas keberagamaan perlu dipahami bersama sebagai realitas alamiah. Kenyataan

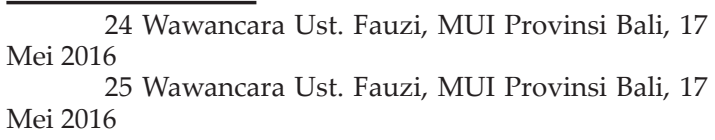

24 Wawancara Ust. Fauzi, MUI Provinsi Bali, 17 25 Wawancara Ust. Fauzi, MUI Provinsi Bali, 17 Mei 2016

\begin{tabular}{l|l} 
Jurnal Multikultural \& Multireligius Vol. 17 & No. 1
\end{tabular} 
ini akan membawa konsekuensi logis dalam kehidupan keberagamaan, yakni tuntutan untuk hidup damai antarkeyakinan. Paradigma dan sikap-sikap yang selama ini cenderung eksklusif, kini diuji dan dipertaruhkan dalam lingkup multireligius di tengah-tengah masyarakat yang multikultural. Kondisi seperti inilah yang sedang terjadi di Denpasar-Bali.

Ada ragam kronik kasus terkait pendirian rumah ibadah masih mewarnai kehidupan keberagamaan di Bali. Akar persoalannya klasik: kurangnya pemahaman masyarakat dan aparat terkait regulasi yang ada, dan lemahnya pengawalan implementasi PBM No. 9 dan 8 Tahun 2006. ${ }^{26}$ Dalam konteks regulasi saat sekarang ini, adanya kewenangan atau kewajiban pemeliharaan kerukunan umat beragama oleh Pemerintah Daerah itu semakin jelas dengan diterbitkannya PBM No. 9 dan 8 Tahun 2006. Secara formal, telah ada aturan terhadap rencana pendirian rumah ibadat. Di Provinsi Bali, Pendirian tempat ibadah diatur berdasarkan Surat Keputusan Gubernur Bali No. 583 Tahun 1991 tentang Prosedur dan Ketentuan-ketentuan Pembangunan Tempat-tempat Ibadah untuk umum di Wilayah Provinsi Daerah Tingkat I Bali. Lima hal penting yang diatur dalam SK tersebut yaitu: (1) Pembangunan tempat-tempat ibadah untuk umum yaitu pura, masjid, wihara, dan gereja harus mendapatkan izin tertulis dari Gubernur

26 Tahun 2006 Pemerintah mengeluarkan Peraturan Bersama Menteri Agama dan Menteri Dalam Negeri (PBM) Nomor 9 Tahun 2006 dan Nomor 8 Tahun 2008 tentang Pedoman Pelaksanaan Tugas Kepala Daerah/Wakil Kepala Daerah dalam Pemeliharaan Kerukunan Umat Beragama, Pemberdayaan Forum Kerukunan Umat Beragama, dan Pendirian Rumah Ibadat. Dalam kaitan ini, ditetapkan bahwa pendirian rumah ibadah didasarkan pada "keperluan nydata dan sungguh-sungguh" serta "komposisi jumlah penduduk" di wilayah bersangkutan. Syarat pendirian rumah ibadah harus memenuhi:Daftar dan dan Kartu Tanda Penduduk pengguna rumah ibadah paling sedikit 90 (sembilan puluh) orang yang disahkan pejabat setempat; Dukungan masyarakat setempat paling sedikit 60 (enam puluh) orang yang disahkan oleh lurah/kepala desa; Rekomendasi tertulis kepala kantor Kepartemen Agama kabupaten/kota; Rekomendasi tertulis FKUB (Forum Kerukunan Umat Beragama) kabupaten/kota.
Kepala Daerah Tingkat I Bali (Pasal 2 ayat 1); (2) Izin yang dimaksud dikeluarkan oleh Gubernur setelah mendapat pertimbangan dari Tim Pertimbangan Pembangunan Tempat-Tempat Ibadah, Kepala Kantor Wilayah Departemen Agama Provinsi Bali, dan Bupati Kepala Daerah Tingkat II setempat (Pasal 2 ayat 2); (3) Surat permohonan izin; (4) Dalam mewujudkan pembangunan tempat ibadah harus menyesuaikan dengan ciriciri khas dari bentuk bangunan tempat ibadah masing-masing agama (Pasal 2 ayat 4); (5) Bupati Kepala Daerah Tingkat II berkewajiban untuk mengawasi pelaksanaan keputusan ini (Pasal 3).

Namun dalam kenyataan di lapangan, realisasi peraturan pendirian rumah ibadat tersebut tidak semudah yang dibayangkan. Sekalipun semua persyaratan formal telah terpenuhi, hal tersebut belum menjadi jaminan akan terwujud pembangunan rumah ibadat dengan mulus. Konflik antara umat Islam dan Hindu berkaitan dengan tempat ibadah sebagian besar bersumber dari perizinan dan pemanfaatan sarana ibadah misalnya sebagai berikut: pertama, penggunaan pengeras suara berkaitan dengan azan dari umat Islam dan Trisandhi dari umat Hindu. Pembacaan Trisandhi pada masa lalu tidak dilakukan dengan menggunakan pengeras suara, namun sekarang beralih menggunakan pengeras suara. Rumah-rumah yang berada di dekat Mushalla maupun Pura seringkali mengeluh karena penggunaan suara dari tempat-tempat ibadah tersebut.

Kedua, penggunaan tempattempat ibadah yang sudah berdiri seringkali menimbulkan konflik atau dipermasalahkan karena berbenturan dengan kepentingan masyarakat setempat terutama pada peringatan hari-hari raya besar yang jatuh pada waktu yang hampir bersamaan. Misalnya ketika bulan puasa ada hari raya agama Hindu, biasanya umat Islam melakukan

\begin{tabular}{l|l} 
HARMONI & Januari - Juni 2018
\end{tabular} 
kompromi-kompromi. Kompromikompromi tersebut difasilitasi oleh Pemda dan kanwil Depag dengan melibatkan majelis-majelis agama yang tergabung dalam FKUB. Namun, kesepakatankesepakatan yang dibuat di tingkat elit seringkali sulit ketika disosialisasikan di tingkat bawah.

Ketiga, permasalahan dalam hal perizinan terutama oleh kalangan minoritas Islam dan Kristen. Salah satu informan dari tokoh agama Islam di Provinsi Bali mengeluhkan betapa sulitnya untuk mendirikan Masjid dan sekolah agama. Hampir semua Masjid yang didirikan di Provinsi Bali diduga tanpa memenuhi persyaratan $40 \mathrm{KK}$ sebagaimana diatur oleh SK Gubernur. Seorang tokoh MUI Provinsi Bali mengatakan bahwa umat Islam merasa kesulitan terutama bertolak dari Instruksi Gubernur yang dijadikan Perda tentang pendirian tempat ibadah yang berkaitan dengan ketentuan izin mendirikan tempat ibadah $^{27}$. Dalam perizinan tersebut terdapat ketentuan bahwa pengusulan tempat ibadah minimal diajukan oleh $60 \mathrm{KK}$ yang dibuktikan dengan fotokopi KTP. Ketentuan lainnya yang dianggap memberatkan, yakni adanya klausul "harus ada persetujuan dari lingkungan." Pengertian lingkungan yang dimaksud tidak ada batasan yang jelas apakah mencakup banjar, desa, atau RT. Dengan demikian, pada praktiknya, pihak-pihak yang berperan dalam pendirian izin adalah Desa Adat atau Desa Pakraman. Hal ini berarti bahwa ketua lingkungan adat di Banjar sebagai pihak yang memiliki peran paling besar dalam menentukan izin. Izin pendirian tempat ibadah sulit diberikan oleh ketua adat karena seringkali dibenturkan dengan tujuan lingkungan yaitu mempertahankan tradisi dan agama Hindu. Demikian juga dengan ijin pendirian gereja. Contoh kasus adalah pembangunan Gereja Kathedral di Renon, Pemda

27 Wawancara Ust. Fauzi, Tokoh Agama \& MUI Provinsi Bali, 17 Mei 2016 tidak memberi izin padahal masyarakat di sekelilingnya sudah memberikan persetujuan ${ }^{28}$. Pemerintah beralasan tanah tersebut tidak dialokasikan untuk tempat ibadah. Akibat banyaknya kasus yang terjadi berkenaan dengan pendirian rumah ibadah di berbagai daerah, muncul wacana perlunya revisi PBM No. 9 dan No. 8 Tahun 2006 tentang Pendirian Rumah Ibadah. Revisi perlu dilakukan khususnya terkait dengan persyaratan jumlah umat sebanyak 90 orang dan persetujuan dari 60 warga di sekitar lokasi pembangunan rumah ibadah.

Sebagaimana dirasakan oleh kalangan umat Islam, umat Kristen juga merasakan kesulitan dalam pembangunan tempat ibadah. Hal itu disebabkan karena adanya ketentuan pendirian rumah ibadah. Ketentuan tersebut memberatkan umat Islam dan Kristen. Namun seringkali masyarakat di kalangan bawah sudah mendukung tapi para pejabat maupun ketua adat tidak memberi izin ${ }^{29}$. Pelaksanaan SK Gubernur No. 583/1991 tentang prosedur pendirian tempat-tempat ibadah mendapat tanggapan yang berbeda-beda dari tokoh-tokoh agama. Permasalahan yang sering timbul di kalangan Kristen adalah persyaratan jumlah KK yang tinggal di lingkungan yang sama sebanyak $60 \mathrm{KK}$. Jumlah tersebut dirasakan kebanyakan karena umat Islam dan Kristen seringkali tinggal di desa yang terpencar-pencar. Padahal, Gereja pada suatu tempat biasanya digunakan oleh umat baik yang berasal dari daerah tersebut maupun dari luar daerah. Hal ini menyebabkan persyaratan $60 \mathrm{KK}$ dianggap membatasi ${ }^{30}$.

Namun demikian, meskipun dinilai membatasi, para tokoh agama ini berpendapat, kebijakan tentang pendirian rumah ibadah tetap diperlukan ${ }^{31}$. Hanya

28 Wawancara Blasius, GKBP Renon, 20 Mei 2016 29 Wawancara Blasius, GKBP Renon, 20 Mei 2016 30 Wawancara Blasius, GKBP Renon, 20 Mei 2016 31 Wawancara Ust. Fauzi, MUI Provinsi Bali, 17 Mei 2016. pernyataan yang sama juga dikemukakan beberapa informan, seperti H. Mustofa, Ida Pangelingsir Agung Putra Sukahet, Ida Bagus Sedhawa, dan Pdt Sudira Husada.

Jurnal Multikultural \& Multireligius Vol. $17 \mid$ No. 
saja, yang perlu dilakukan adalah merevisi kebijakan tersebut dengan memperhatikan memperhatikan adat istiadat setempat ${ }^{32}$. Permasalahan lainnya ditengarai terletak pada tataran implementasi dan minimnya sosialisasi. Dalam implementasinya, perlu ada semacam TOR $^{33}$ untuk implementasi UU tersebut dan juga pengawalan di lapangan ${ }^{34}$.

Ketentuan PBM yang menyatakan bahwa rekomendasi tentang usul IMB rumah ibadat hendaklah diputuskan melalui rapat secara musyawarah/ mufakat akan tetapi pada kenyataannya masih cukup sulit. Lemahnya solidaritas di kalangan para pemuka agama pada dasarnya merupakan kelanjutan dari belum terselesaikannya pemahaman masyarakat tentang pengertian dari semangat misi pada setiap agama. Pemerintah Daerah maupun Kemenag secara umum juga belum melihat hal itu sebagai prioritas pembangunan oleh karena penanganan yang serba tanggung terhadap program pemeliharaan kerukunan umat beragama. Akibatnya, sudah diduga bahwa format relasi di antara umat beragama masih terpola pada konstruk mayoritas dan minoritas.

Masyarakat masih memahami bahwa letak keberagamaan itu adalah pada angka nominal jumlah penganut suatu agama. Sebutan mayoritas dan minoritas secara jujur harus diakui bahwa hal itu hanyalah sebuah pengandaian angka statistik sebagai bahan penyusunan kebijakan pelayanan terhadap pengamalan ajaran agama. Inti persoalannya adalah perlunya rumusan paradigma keberagamaan di Indonesia agar pemahaman terhadap misi agama tetap sejalan dengan nasionalisme.

\footnotetext{
32 Wawancara Ida Bagus Sedhawa, Kepala Badan Diklat Provinsi Bali, 20 Mei 2016

33 Wawancara H. Mustofa, FKUB Denpasar, 19 Mei 2016 dan hasil kesimpulan FGD

34 Wawancara Ust. Fauzi, MUI Provinsi Bali, 17 Mei 2016. pernyataan yang sama juga dikemukakan beberapa informan, seperti $H$. Mustofa, Ida Bagus Sedhawa, Pdt Sudira Husada, dan Blasius GKBP Renon.

\begin{tabular}{l|l} 
HARMONI & Januari - Juni 2018
\end{tabular}
}

\section{Melemahnya Solidaritas Kultural Akibat Pola Segregasi Sosial}

Pola segregasi sosial banyak ditemukan pada Desa Pakraman yang multietnis (Atmadja, 2002). Penelitian Atmadja (2002) di Desa Pakraman Pangestulan, menunjukkan pola pemukiman mereka yang segregasi sosial. Warga muslim mengelompok di Banjar Kauman, sedangkan warga Hindu mengelompok di Banjar Pala, Sari, dan Purwa. Akibatnya, mereka lebih banyak bergaul dengan komunitas mereka. Hal ini dapat menyebabkan rapuhnya rasa solidaritas sosial antar agama maupun antaretnis yang disebabkan oleh masyarakat yang meskipun berada dalam ruang yang sama, namun mereka berjalan sendiri-sendiri tanpa memahami yang lainnya. hal ini juga diperparah dengan memudarnya tradisi-tradisi yang menjadi tiang penyangga solidaritas antaretnis atau antaragama. Seperti dikemukakan Atmadja (2010: 384), banyak Tradisi masyarakat Bali yang diadaptasikan, dimarjinalkan, bahkan disingkirkan Karena tidak sesuai dengan modernitas. Sebagai contoh, memudarnya tradisi ngejot yang menjadi tiang penyangga solidaritas antaretnis atau antaragama. Tradisi Ngejot, Oleh kaum modernis, didekonstruksi dari segi hukum Islam tentang halal dan haram. Pada akhirnya, hal ini tidak pernah mendapatkan pemaknaan yang sama dikalangan umat Islam, apakah tradisi ngejot ini halal atau haram. Oleh Karena itu, daripada berdosa Karena kedudukannya yang belum jelas apakah halal atau haram, maka banyak orang Islam yang menghapuskan tradisi ini daripada mempertahankannya. Padahal, Ngejot merupakan modal kultural terkait dengan simbol solidaritas sosial atau Menyama Braya antaretnis atau antaragama.

Melemahnya solidaritas kultural saat ini, juga merupakan akibat dari menguatnya paham Ke-Kita-an dan 
Ke-Mereka-an (Atmadja, 2010:288), hal ini sangat berpotensi memicu terjadinya konflik. Kehadiran etnik non-Bali dan agama non-Hindu pada Desa Pakraman mengakibatkan struktur sosial Desa Pakraman terpilah menjadi dua yakni, warga muwed (asli) dan tamiu (pendatang). Warga muwed acapkali dianggap berkedudukan lebih tinggi daripada warga tamiu. Hal ini tidak semata-mata bertalian dengan posisi sosial, melainkan berkaitan pula dengan peran kemasyarakatan yang di dalamnya menyangkut siapa yang memiliki akses, dan siapa yang memiliki wewenang untuk membuat keputusan (Atmadja, 2004).

Dalam melihat hubungan antara warga muwed dan tamiu, mereka tidak selamanya menempatkan dalam hubungan yang saling melengkapi, melainkan sebagai dua unsur yang berlawanan. Seperti dikemukakan oleh Fay, dualisme dikotomik bisa mendorong terjadinya suatu pertentangan antara dua entitas dan kekuatan yang harus dipilih keberpihakannya, yakni pihak ini atau pihak itu (dalam Atmadja, 2004). Bersamaan dengan itu, konflik yang semula bersifat perebutan sumber daya ekonomi maupun politik bisa berubah menjadi konflik antara kita dan mereka, muwed dan tamiu, atau Bali melawan etnik non-Bali. Mengutip Tumanggor (2009:1112), Individu-individu dalam masyarakat dengan konfigurasi pemilahan sosial yang terkonsolidasi cenderung lebih mudah melakukan subyektivitas konflik. Mereka juga lebih mudah untuk menerjemahkan konflik yang menyangkut kondisi obyektif (objective conflict) menjadi konflik yang menyangkut pribadi (subjective conflict), misalnya konflik mengenai persoalan ekonomi atau kriminal biasa berkembang menjadi konflik etnik atau konflik agama, baik konflik antar agama yang berbeda (inter-religious conflict) maupun konflik antar umat satu agama (intra-religious conflict).
Selain itu, munculnya sekolahsekolah bercorak agama (terutama Agama Islam), mulai dari Madrasah Ibtidaiyah (Setingkat SD), Madrasah Tsanawiyah (Setingkat SMP), dan Madrasah Aliyah (setingkat SMA) juga menjadi salah satu tantangan tersendiri dalam memupuk interaksi sosial lintas etnis maupun lintas agama di Bali. Jumlah sekolah-sekolah bercorak Islam ini terus meningkat dari tahun ke tahun. Jika pada tahun 2008, sekolah Agama (Islam) berjumlah 88 (Madrasah Ibtidaiyah, Madrasah Tsanawiyah dan Madrasah Aliyah), jumlah ini terus meningkat hingga tahun 2013 yang mencapai 111 sekolah (Kemenag Propinsi Bali, 2013).

Di satu sisi, adanya sekolahsekolah bercorak agama ini sangat baik untuk memberikan modal intelektual dan modal agama kepada peserta didik. Namun, di sisi lain, pemisahan peserta didik berdasarkan agama tidak bisa dihindarkan. Hal ini menimbulkan interaksi sosial lintas etnis maupun lintas agama menjadi terbatas. Bahkan, seperti dikemukakan Yaqin (2005) dalam sekolah seperti ini, selalu bisa terjadi berkembangnya paradigma keberagamaan yang eksklusif. Dengan demikian, menjadi tantangan bagi lembaga-lembaga pendidikan ini untuk secara intensif menerapkan pendidikan multikultural, dialog antaragama, dan dialog budaya untuk menumbuhkan paradigma inklusif dalam bidang agama dan kebudayaan di kalangan peserta didik. Apabila hal ini diterapkan secara intensif, maka paradigma eksklusifitas keagamaan maupun kebudayaan, serta pengentalan faham ke-kita-an dan kemereka-an baik di kalangan orang Bali maupun non-Bali dapat diminimalisir.

Apa yang telah penulis kemukakan di atas sebenarnya telah mengisyaratkan bahwa solidaritas-solidaritas kultural telah menjadi modal kultural yang kuat dalam menjaga keharmonisan antarumat 
beragama di Bali. Modal kultural yang berakar kuat dalam sejarah itu sebetulnya masih ada. Namun, solidaritas-solidaritas kultural itu dalam perkembangannya bisa saja kalah oleh kekuatan-kekuatan sosial dan ekonomi yang baru. Namun, yang harus disadari adalah jika tak dirawat, modal kultural itu dapat habis tergerus. Dalam kondisi ini, agama dapat berubah menjadi potensi konflik. Modal sosial dan agama ini perlu terus dinarasikan kembali kepada masyarakat agar keteladanan sejarah tetap menjadi memori kolektif bagi masyarakat Bali.

\section{SIMPULAN}

Secara umum Provinsi Bali merupakan wilayah damai, tetapi terdapat potensi dan gejala konflik. Beberapa konflik kecil yang terjadi berpangkal pada masalah utama yaitu pendekatan dan relasi sosial yang kurang antarumat beragama. Sebagai daerah wisata internasional, heterogenitas dan posisi Bali sangat memungkinkan potensi konflik menjadi konflik terbuka karena berbagai kepentingan.

Studi ini telah menunjukkan bahwa kearifan lokal sendiri dalam masyarakat sebenarnya memiliki potensi dalam merajut kohesivitas masyarakat Bali yang majemuk. Selain itu, struktur Adat, dan juga didukung oleh peran pemerintah, tokoh agama dan FKUB dalam menjaga kerukunan antarumat beragama. Konsensus bersama antara semua elemen untuk mengantisipasi dan menjaga kondisi damai diwujudkan melalui relasi dan kordinasi antara pemerintah, tokoh adat dan pemuka agama. "Kepentingan bersama" menjadi faktor utama untuk menciptakan dan mempertahankan kondisi damai. Dalam konteks ini, faktor utama tersebut ialah pariwisata.
Pariwisata terkait langsung dengan kenyamanan, keamanan dan kedamaian. Terganggunya pariwisata menyebabkan terganggunya semua aspek kehidupan. Namun, dalam kondisi masyarakat Bali yang heterogen, terdapat potensi yang dapat menjadi memicu konflik, yaitu stereotip berlatar belakang agama dan etnis, relasi dan pendekatan sosial yang kurang komunikatif, perbedaan tradisi dan budaya antara penduduk lokal dan pendatang, serta rivalitas antara penduduk lokal dan pendatang dalam memperebutkan ruang-ruang ekonomi.

Beberapa catatan penting yang patut menjadi perhatian kita bersama dalam upaya menjaga harmoni sosial tetap terjaga antara lain dengan memperbesar ruang temu budaya dan dialog antar agama untuk membuka sikap saling memahami antarbudaya dan antaragama. Karenanya, perlu ditinjau kembali faktorfaktor yang mendorong pandangan etnosentrisme dan budaya dominan dengan mempertimbangkan strategi multikulturalisme guna mencairkan batas-batas budaya.

\section{UCAPAN TERIMA KASIH}

Di akhir tulisan ini, penulis sangat berterima kasih kepada Kepala LIPI yang telah memberikan kesempatan kepada penulis untuk melakukan penelitian tentang isu yang diangkat dalam tulisan ini, juga beberapa pihak dan informan yang terlibat dalam penggalian data dan informasi di dalamnya. Tidak ketinggalan, terima kasih juga penulis tujukan kepada Mitra Bestari dan Pengelola Jurnal Harmoni yang telah memberikan catatan dan saran untuk perbaikan tulisan ini, hingga bisa diterbitkan pada Jurnal Harmoni edisi kali ini. 


\section{DAFTAR ACUAN}

Ali. Mukti. 1994. "Dialog dan Kerjasama Agama dalam Menanggulangi Kemiskinan”, dalam Wienata Saiirin, Dialog antarumat Beragama: Membangun Pilar-pilar Keindonesiaan yang Kokoh. Jakarta: BPK Gunung Mulia

Abubakar, H.M., Muhammad. 2010. Falsafah Hidup Budaya: Huma Betang dalam Membangun Kerukunan Umat Beragama di Kota Palangka Raya, Kalimantan Tengah. Malang: Aditya Media Publising.

Ali-Fauzi, Ihsan \& Robert W Hefner. 2014. Mengelola Keragaman. Yogyakarta: CRCS UGM

Asfinawati et.al. 2008. Kekerasan terhadap Jama'ah Ahmadiyah di Manislor Kuningan, Jawa Barat, dan Lombok, NTB; Kekerasan terhadap Jama'ah Al Qiyadah Al Islamiyah Siroj Jaziroh Padang, Sumatera Barat; Kekerasan terhadap Jemaat Gereja di Bandung, Jawa Barat. Laporan Investigasi.

Atmadja. Nengah Bawa. 1998. Memudarnya Demokrasi Desa: Pengelolaan Tanah Adat, Konversi dan Implikasi Sosial dan Politik di Desa Adat Julah, Buleleng, Bali. (Disertasi tidak diterbitkan pada Jurusan Antropologi, Program Pascasarjana Universitas Indonesia).

2002. Reformasi ke Arah kemajuan yang Sempurna dan Holistik Gagasan Surya Kanta tentang Bali di Masa Depan. Surabaya: Paramita

2004. Manajemen Konflik pada Desa Adat Multietnik di Kabupaten Buleleng Bali. Laporan Penelitian Hibah Bersaing. Singaraja: IKIP Negeri Singaraja

Globalisasi. Yogyakarta: LKIS

2010. Ajeg Bali: Gerakan, Identitas Kultural, dan

Azhari, M. Subhi, Rumadi Ahmad, dan Nurun Nisa. 2012. Laporan Akhir Tahun Kebebasan Beragama dan Intoleransi 2012. Jakarta: The Wahid Institute.

Azra, Azyumardi. 1999. Konteks Berteologi di Indonesia: Pengalaman Islam.Jakarta: Paramadina

Basyir, Kunawi. 2013. Pola Kerukunan Antarumat Islam dan Hindu di Denpasar Bali. ISLAMICA, Vol. 8 (1): 1-27

Bush, Robin. 2008. "Regional Sharia Regulations in Indonesia: Anomaly or Symptom?" Dalam Greg Fealy \& Sally White (eds.), Expressing Islam: Islamic Life and Politics in Indonesia. Singapore: Institute of Southeast Asian Studies.

Denzin, Norman K., Yvonna S. Lincoln (eds.). 1994. Handbook of Qualitative Research (2nd ed.). Thousand Oaks: Sage Publications

Dwipayana, Ari, 2003. “Catatan Kritis Pelaksanaan Otonomi Tingkat Desa di Bali” dalam Karim, Abdul Gaffar, (ed), Kompleksitas Persoalan Otonomi Daerah di Indonesia, Yogyakarta: Pustaka Pelajar dan Jurusan Ilmu Pemerintahan Fisipol UGM

Perda Provinsi Bali No. 3 Tahun 2001. Tentang Desa Pakraman, Bali: Biro Hukum dan HAM Setda Bali. 
Cholil, Suhadi, Zainal Abidin Bagir, Moh. Iqbal Ahnaf, Marthen Tahun, Budi Ashari. 2013. Laporan Tahunan Kehidupan Beragama di Indonesia tahun 2012. Yogyakarta: Program Studi Agama dan Lintas Budaya, Universitas Gadjah Mada

Clifford Geertz, "Religion as a Cultural System", dalam R. Banton, Antropological Approach to the Study of Religions (Canada: Basic Book Inc, 1965), 127.

Haba, John. 2008. “Revitalisasi Kearifan Lokal: Studi Resolusi Konflik di Kalimantan Barat, Maluku dan Poso," dalam Irwan Abdullah, dkk. (ed.), Agama dan Kearifan Lokal dalam Tantangan Global, Yogyakarta: Pustaka Pelajar.

Hamid, Sandra. 2012. "Indonesian Politics in 2012: Coalitions, Accountability and the Future of Democracy." Bulletin of Indonesian Economic Studies 48 (3): 325-345.

Human Rights Watch (HRW). 2013. In Religion's Name: Abuses against Religious Minorities in Indonesia. New York: Human Rights Watch.

INFID. 2013. Laporan Kebebasan Beragama di Indonesia 2010-2012. Jakarta: INFID

International Crisis Group (ICG). 2008. Indonesia: Implikasi SKB (Surat Keputusan Bersama) tentang Ahmadiyah. Asia Briefing No. 78. Jakarta/Brussels: ICG.

2012. Indonesia: Akibat Fatal dari Pemolisian yang Lemah. Asia Report No. 218. Jakarta/Brussels: ICG.

I W. Juniartha. 2005. "Bom Bali Jimbaran Kuta Melawan Mereka yang Tak Takut Mati", dalam Atmadja. 2010. Ajeg Bali: Gerakan, Identitas Kultural, dan Globalisasi. Yogyakarta: LKIS

Khisbiyah, Yayah. 2007. Menepis Prasangka, Memupuk Toleransi untuk Multikulturalisme: Dukungan dari Psikologi Sosial. Surakarta: PSB-PS UMS.

Kontras (Komisi untuk Orang Hilang dan Korban Tindak Kekerasan). 2012. Panduan Pemolisian \& Hak Berkeyakinan, Beragama dan Beribadah. Jakarta: Kontras.

Muhtadi, Burhanuddin. 2011. “Demokrasi zonder Toleransi: Potret Islam Pasca Orde Baru." dalam Rizal Panggabean \& Ihsan Ali-Fauzi. 2014. Pemolisian Konflik Keagamaan di Indonesia. Jakarta: PUSAD Paramadina

Naim, Akhsan., Hendri Saputra. 2010. Kewarganegaraan, Suku Bangsa Agama, Dan Bahasa sehar-hari Penduduk Indonesia, Hasil Sensus tahun 2010, Jakarta: Badan Pusat Statistik.

Naipospos, Bonar Tigor, Halili, Ismail Hasani, Abdul Khoir, Agnes Hening Ratri, Aminuddin Syarif, Akhol Firdaus, Bahrun, Hilal Safari, dan M. Irfan. 2013. Leadership without Initiative: The Condition of Freedom of Religion/Belief in Indonesia 2012. Jakarta: Pustaka Masyarakat Setara.

Nasikun. 1992. Sistem Sosial Indonesia. Jakarta: Rajawalipress

Pageh, I. M., Wayan Sugiartha, Ketut Sedana Artha. 2013. Analisis Faktor Integratif Nyama Bali-Nyama Selam, Untuk Menyusun Buku Panduan Kerukunan Masyarakat Di Era Otonomi Daerah. Jurnal Ilmu Sosial Dan Humaniora, Vol. 2 (2): 239-248

Patoni, Achmad. 2007. Peran Kyai Pesantren dalam Partai Politik. Yogyakarta: Pustaka Pelajar. 
Puslitbang Kehidupan Keagamaan Badan Litbang dan Diklat Kementerian Agama RI. 2016. Laporan Tahunan Kehidupan Keagamaan di Indonesia Tahun 2015. Jakarta: Badan Litbang dan Diklat Kementerian Agama RI

Salim, Hairus, Najib Kailani \& Nikmal Azekiyah. 2011. Politik Ruang Publik Sekolah: Negosiasi dan Resistensi di Sekolah Menengah Umum Negeri di Yogyakarta. Yogyakarta: Center for Religious and Cross-cultural Studies (CRCS), Universitas Gadjah Mada.

Sanjaya, Dewa Bagus., Wayan Sugiartha. 2013. Harmonisasi, Integrasi Desa Pakraman dengan Desa Dinas yang Multi Etnik dan Multiagama Menghadapi Pergeseran, Pelestarian, dan Konflik di Bali. Jurnal Ilmu Sosial dan Humaniora (2) 2: 265-276

Setia, Putu (ed). 1993. Suara Kaum Muda Hindu. Jakarta: Yayasan Dharma NusantaraFCHI

Suastika, I Made. 2005. "Berpikir Positif dalam Budaya Bali” dalam PaEni, Mukhlis dan Pudentia (ed). Bunga Rampai Budaya berpikir Positif Suku-suku Bangsa. Jakarta: Departemen Kebudayaan dan Pariwisata \& Asosiasi Tradisi Lisan.

Suparlan. 2004. Masyarakat Majemuk, Masyarakat Multiultural, dan Minoritas: Memperjuangakan Hak-hak Minoritas. Makalah dalam Workshop Yayasan Interseksi, Hak-hak Minoritas dalam Landscape Multikultural, Mungkinkah di Indonesia?, Wisma PKBI, 10 Agustus 2004. Dalam http://www.interseksi.org/ publications/essays/articles/masyarakat_majemuk.html diunduh 26 Juli 2016

Suprapto. 2012. Antara Mayoritas dan Minoritas: (Telaah Kritis atas Peran Negara dan Umat Islam dalam Mengembangkan Demokrasi di Indonesia). Jurnal Analisis, Volume XII, Nomor 1, 19-47

Titib, I. M. 2012. Purana Sumber Ajaran Hindu Komprehensif. Surabaya: Paramita

Tumanggor, Rusmin (et.al). 2009. Buku Paket Panduan Penyadaran Dan Pendampingan Penguatan Kedamaian (Peace Making). Jakarta: Departemen Agama Republik Indonesia, Badan Litbang Dan Diklat, Puslitbang Kehidupan Keagamaan.

Wahid Institute. 2012. Islam dan Kaum Minoritas: Tantangan Kontemporer, Jakarta: The Wahid Institute.

2014. Laporan Tahunan Kebebasan Beragama /Berkeyakinan dan Intolerasi 2014, “Utang” Warisan Pemerintah Baru. Jakarta: The Wahid Institute 